\title{
ANALISIS KEPUASAN SATUAN KERJA PERANGKAT DAERAH (SKPD) DAN REKANAN TERHADAP KINERJA UNIT LAYANAN PENGADAAN (ULP) PEMERINTAH KABUPATEN BADUNG
}

\author{
Putu Budayasa ${ }^{1}$, I M.Alit K. Salain², Mayun Nadiasa²
}

\begin{abstract}
Abstrak:Berdasarkan Peraturan Presiden Nomor 54 Tahun 2010 tentang Pengadaan Barang/Jasa Pemerintah,proses pengadaan barang/jasa dilaksanakan oleh suatu unit yang disebut Unit Layanan Pengadaan (ULP). ULP Pemerintah Kabupaten Badung dibentuk pada tahun 2011 dimana dalam melaksanakan proses pengadaan barang/jasa sering mendapatkan praduga negatif dari pihak yang berhubungan dengan unit tersebut yaitu pihak SKPD dan Rekanan. Berdasarkan hal tersebut maka perlu dilakukan evaluasi terhadap pelayanan yang telah diberikan. Penelitian yang dilakukan bertujuan untuk mengetahui tingkat kepuasan SKPD dan Rekanan terhadap kinerja Unit Layanan Pengadaan (ULP) Pemerintah Kabupaten Badung serta untuk mengetahui pengaruh lima dimensi kualitas pelayanan yang mempengaruhi kepuasan SKPD dan Rekanan yaitu Tangible, Reliability, Responsiveness, Assurance dan Empathy.

Penentuan sampel menggunakan teknik Simple Random Samplingyaitu 30 dari SKPD dan 71 dari Rekanan.Pengukuran tingkat kepuasan dilakukan dengan cara membandingkan skor harapan dengan skor persepsi responden terhadap kenyataan pelayanan yang diterima. Sedangkan untuk mengetahui dimensi yang mempengaruhi kepuasan Rekanan dan kepuasan SKPD dilakukan dengan mencari model persamaan regresi linear bergandasehingga diketahui pengaruh atau hubungan antara variabel baik secara parsial maupun secara simultan.

Hasil analisis diskriptif menyatakan tingkat kepuasan SKPD terhadap pelayanan ULP Pemerintah Kabupaten Badung secara keseluruhan adalah sebesar 86,28\%, dimana faktor yang paling mempengaruhi kepuasan tersebut adalahAssurance. Tingkat kepuasan Rekanan adalah sebesar 86,4\% dimana faktor yang paling mempengaruhi kepuasan tersebut adalahTangible. Hasil analisis inferensial menyatakan bahwa kelima dimensi tersebut berpengaruh secara simultan dan parsial terhadap kepuasan baik SKPD maupun Rekanan.
\end{abstract}

Kata Kunci : Unit Layanan Pengadaan, Kepuasan, Pengadaan Barang/Jasa

\section{REGIONAL WORK UNIT AND PARTNER COMPANY SATISFACTION ANALYSIS ON THE PERFORMANCE OF PROCUREMENT SERVICE UNIT OF BADUNG REGENCY}

Abstract : Based on Presidential Decree Number 54 Year 2010 concerning Government Procurement of Goods / Services. Procurement process carried out by a unit called the Procurement Service Unit (PSU). In Government of Badung Regency, PSU was formed in 2011wich often get a negative presumption of those associated with the Unit is the Regional Work Unit and Partner Company when carry out the procurement process. Under these conditions it is necessary to evaluate the services given. The research aimed to determine the level of satisfaction Regional Work Unit and Partner Company of the performance of the Procurement Unit of Badung Regency and to investigate the influence of the five dimensions of service quality and satisfaction levels wich is Tangible, Reliability, Responsiveness, Assurance and Empathy.

Sampling using simple random sampling with a sample of 30 of Regional Work Unit and 71 of the Partner Company. Measuring the level of satisfaction is done by comparing the scores of hope with a score of respondents' perceptions of reality services received. While to know the factors that influence satisfaction of Partner company and regional work unit done by searching multiple linear regression model. The analysis was conducted to determine the effect or the relationship between variables, either partially or simultaneously.

The results of descriptive analysis expressed Regional Work Unit satisfaction level is $86.28 \%$, which factors most influence satisfaction is Assurance. Partner Company satisfaction level is $86.4 \%$ which factors most influence satisfaction is Tangible. Results inferential analysis states that the fifth dimension is influenced simultaneously and partially on both Regional Work Unit and Partner Company satisfaction .

Keywords : Procurement Unit, Satisfaction, Procurement of Goods / Services

\footnotetext{
${ }^{1}$ Mahasiswa Program Magister Teknik Sipil, Program Pascasarjana, Universitas Udayana, Denpasar

${ }^{2}$ Staf Pengajar Program Magister Teknik Sipil, , Program Pascasarjana, Universitas Udayana, Denpasar
} 


\section{PENDAHULUAN}

\section{Latar Belakang}

Proses pelaksanaan Pengadaan Barang/Jasa Pemerintah dilaksanakan oleh suatu Unit Layanan Pengadaan (ULP) sesuai dengan ketentuan Peraturan Presiden Nomor 54 Tahun 2010 tentang Pengadaan Barang/Jasa Pemerintah Pasal 1 ayat 8 "Unit Layanan Pengadaan yang selanjutnya disebut ULP adalah unit organisasi pemerintah yang berfungsi melaksanakan Pengadaan Barang/Jasa di Kementrian/Lembaga/Satuan Kerja Perangkat Daerah/Institusi Lainnya yang bersifat permanen, dapat berdiri sendiri atau melekat pada unit yang sudah ada”. ULP Pemerintah Kabupaten Badung dibentuk berdasarkan Peraturan Bupati Badung Nomor 70 Tahun 2011 tentang Pembentukan Unit Layanan Pengadaan (ULP) Pemerintah Kabupaten Badung. ULP pada Pemerintah Kabupaten Badung bersifat fungsional, dimana keberadaannya masih melekat pada Bagian Administrasi Pembangunan Sekretariat Daerah Kabupaten Badung. Pengadaan Barang/Jasa dalam ULP dilaksanakan oleh 9 (Sembilan) Kelompok Kerja (Pokja) yang anggotanya berada dibawah koordinasi Bagian Administrasi Pembangunan Sekretariat Daerah Kabupaten Badung. Pelaksanaan pengadaan barang/jasa (pelelangan) yang dilaksanakan oleh ULP Pemerintah Kabupaten Badung mencakup seluruh proses pengadaan barang/jasa yang dilaksanakan diseluruh Instansi di lingkungan Pemerintah Kabupaten Badung yang pendanaannya melalui Anggaran Pendapatan Belanja Daerah (APBD) atau Anggaran Pendapatan Belanja Negara (APBN).

Proses pemilihan penyedia barang/jasa yang dilaksanakan secara tertutup oleh ULP sering memunculkan berbagai praduga baik dari pihak SKPD maupun calon penyedia barang/jasa. Secara umum, dari pihak SKPD praduga yang muncul antara lain ULP diduga tidak netral dalam melaksanakan proses pemilihan penyedia barang/jasa, tidak teliti dalam melakukan evaluasi, mempersulit proses pendaftaran paket pengadaan dengan membuat persyaratan yang cukup banyak, mengulur waktu dalam proses pengadaan dengan mencari-cari kesalahan dalam dokumen pengadaan, tidak melakukan prosedur pelelangan dengan baik dan benar. Sedangkan dari pihak calon penyedia barang/jasa praduga yang muncul antara lain ULP memiliki calon penyedia barang/jasa untuk dipilih sebagai pemenang pemilihan penyedia barang/jasa, mempersulit akses kejaringan SPSE karena calon penyedia merasa sering sulit untuk melakukan log in ke halaman SPSE, selain kesulitan $\log$ in, penyedia juga sering mengalami kesulitan dalam mengunggah dokumen penawaran, tidak konsisten dalam melaksanakan evaluasi penawaran sehingga sering merugikan calon penyedia, melakukan kecurangan dalam pengumuman pelelangan karena banyak pengumuman lama hilang dari jendela SPSE,dantidak melaksanakan prosedur pelelangan yang sudah tertuang dalam Perpres dengan baik dan benar.

Praduga yang muncul dari pihak SKPD maupun pihak calon penyedia akan memunculkan ketidakpuasan terhadap kinerja ULP Pemerintah Kabupaten Badung. Apabila SKPD tidak puas akan kinerja ULP maka PPK kegiatan dapat menolak melakukan penandatanganan Surat Penunjukan Penyedia Barang/Jasa (SPPBJ) dan meminta evaluasi ulang sehingga memperpanjang proses pengadaan penyedia barang/jasa. Sedangkan apabila dari calon penyedia barang/jasa tidak puas maka mereka dapat melakukan sanggahan terhadap proses pemilihan penyedia barang/jasa yang dilakukan ULP.

Berdasarkan praduga yang muncul dan dengan adanya proses sanggahan yang sudah terjadi serta mengingat ULP Pemerintah Kabupaten Badung sudah berdiri selama 3 (tiga) tahun tentu diperlukan perbaikan dan penyempurnaan diantaranya melalui penelitian untuk mengetahui kepuasan SKPD dan Rekanan terhadap pelayanan yang telah diberikan dan juga elemen penting sebagai evaluasi sehingga mampu memberikan pelayanan yang lebih baik, lebih efektif dan lebih efisien.

\section{Perumusan Masalah}

Pokok masalah penelitian ini adalah:

1. Bagaimana tingkat kepuasan SKPD dan Rekanan terhadap kinerja ULP Pemerintah Kabupaten Badung dilihat dari Proses Pemilihan Penyedia Barang/Jasa berdasarkan Peraturan Presiden Nomor 54 Tahun 2010.

2. Bagaimana hubungan antara faktor-faktor yang mempengaruhi kepuasan SKPD dan rekanan terhadap kinerja ULP Pemerintah Kabupaten Badung.

\section{Tujuan Penelitian}

Penelitian bertujuan untuk mengetahui tingkat kepuasan SKPD dan Rekanan terhadap kinerja ULP Pemerintah Kabupaten Badung dan untuk mengetahui hubungan antara dimensi yang mempengaruhi kepuasan SKPD dan rekanan terhadap kinerja ULP Pemerintah Kabupaten Badung.

\section{TINJAUAN PUSTAKA}

\section{ULP dan Proses Pengadaan Barang/Jasa}

Pengadaan Barang/Jasa Pemerintah yang selanjutnya disebut dengan Pengadaan Barang/Jasa adalah kegiatan untuk memperoleh Barang/Jasa oleh Kementerian/Lembaga/Satuan Kerja Perangkat 
Daerah/Institusi lainnya yang prosesnya dimulai dari perencanaan kebutuhan sampai diselesaikannya seluruh kegiatan untuk memperoleh Barang/Jasa.

Kementerian/Lembaga/Satuan Kerja Perangkat Daerah/Institusi lainnya, yang selanjutnya disebut $\mathrm{K} / \mathrm{L} / \mathrm{D} / \mathrm{I}$ adalah instansi/institusi yang menggunakan Anggaran Pendapatan dan Belanja Negara (APBN) dan/atau Anggaran Pendapatan dan Belanja Daerah (APBD)

Unit Layanan Pengadaan yang selanjutnya disebut ULP adalah unit organisasi pemerintah yang berfungsi melaksanakan Pengadaan Barang/Jasa di $\mathrm{K} / \mathrm{L} / \mathrm{D} / \mathrm{I}$ yang bersifat permanen, dapat berdiri sendiri atau melekat pada unit yang sudah ada.

\section{Kepuasan Pelanggan}

Salah satu teknik dalam mengukur sikap pelanggan adalah dengan menggunakan kuisioner. Perusahaan harus merancang kuisioner kepuasan pelanggan yang secara akurat dapat memperkirakan persepsi/harapan pelanggan tentang mutu barang atau jasa.

Kotler (2000:3) menyampaikan empat metode untuk menilai kepuasan pelanggan yaitu :

1. Sistem keluhan dan saran (complaint and suggestion system)

2. Survey kepuasan pelanggan (customer satisfaction surveys)

3. Belanja siluman (ghost shopping)

4. Analisis kehilangan pelanggan

Untuk mengevaluasi jasa atau pelayanan yang bersifat intangible, ada lima dimensi pengukuran yang dilakukan (Parasuraman, 1988:16), yaitu :

1. Reliability (Keandalan)

Kemampuan dalam memberikan pelayanan dengan segera, akurat dan memuaskan.

2. Responsiveness (Daya tanggap)

Daya tanggap karyawan untuk membantu para pelanggan dan memberikan pelayanan yang tanggap. Dimensi ini menekankan pada perhatian dan keseriusan dalam menanggapi permintaan pelanggan, pertanyaan yang diajukan pelanggan, pengaduan dan masalah yang dihadapi.

3. Assurance (Jaminan atau Keyakinan)

Meliputi pengetahuan, kemampuan, kesopanan, dan sifat dapat dipercaya yang dimiliki para staf/karyawan.

4. Emphaty (Empati)

Mencakup kemudahan hubungan, komunikasi, perhatian dan memahami kebutuhan para pelanggan.

5. Tangibles (Berwujud atau Bukti langsung)

Mencakup fasilitas fisik, perlengkapan, dan sarana prasarana.

Untuk menentukan kepuasan pelanggan diperlukan data yang menggambarkan lima faktor di atas yang diwujudkan dalam bentuk harapan dan kenyataan. Data dikumpulkan dengan metode survei.

Data yang sudah terkumpul diolah dengan menggunakan metode yang disebut oleh Zeithaml dan Parasuraman dengan metode ServQual (service Quality) yang menggambarkan dan menerangkan tingkat kepentingan pelanggan atau responden secara mutu dan kuantitas.

\section{METODE PENELITIAN}

Sampel penelitian bersumber dari SKPD dan Rekanan yang menggunakan layanan ULP Pemerintah Kabupaten Badung pada Tahun Anggaran 2013. Responden dari SKPD yang dipakai adalah mereka yang berhubungan langsung dengan ULP yaitu PPK dan PPTK dari 3 SKPD dengan paket terbanyak dengan jumlah 30 orang. Responden dari Rekanan berjumlah 71 orang yang diambil dari jumlah Rekanan yang mengikuti proses pengadaan barang/jasa di ULP Kabupaten Badung pada TA. 2013 yang berjumlah 249 Rekanan.Penentuan sampel menggunakan Simple Random Sampling danproses analisa dibantu dengan program SPSS.

Pengukuran tingkat kepuasan dilakukan dengan cara membandingkan skor harapan dengan skor persepsi responden terhadap kenyataan pelayanan yang diterima. Dari hasil perbandingan tersebut akan dapat diketahui tingkat kepuasan responden. Analisis dilanjutkan dengan memasukkan dimensi yang mempengaruhi kepuasan ke dalam diagram kartesius yang terdiri dari empat kuadran. Dari diagram ini akan terlihat dimensi mana yang perlu mendapat perhatian khusus untuk meningkatkan kepuasan, mana yang sudah baik dan perlu dipertahankan dan mana yang terlalu berlebihan.

Kuadran A :merupakan dimensi yang dianggap sangat penting, namun belum dilaksanakan sesuai keinginan pelanggan sehingga tidak memuaskan.

Kuadran B :merupakan dimensi yang dianggap sangat penting dan sangat memuaskan.Telah berhasil dilaksanakan, sehingga wajib dipertahankan.

Kuadran $\mathbf{C}$ :merupakan dimensi yang kurang penting pengaruhnya, pelaksanaannya biasa-biasa saja dan kurang memuaskan.

Kuadran D :merupakan dimensi yang dianggap kurang penting tetapi sangat memuaskan.

Untuk mengetahui hubungan antara dimensi yang mempengaruhi kepuasan SKPD dan rekanan terhadap kinerja ULP Pemerintah Kabupaten Badung digunakan analisis regresi linear berganda.

Analisis regresi dilakukan pada tingkat 95\% ( $\alpha$ $=0,05$ ) dan menggunakan metode enter, yaitu semua variabel independen dimasukkan secara bersama dalam model perhitungan, kemudian melihat nilai $\mathrm{t}$ 
hitung untuk dibandingkan dengan angka kritis pada tabel $t$ atau dengan melihat tingkat signifikannya dan membandingkannya dengan nilai $\alpha=0,05$.

Model regresi untuk kepuasan Rekanan dan SKPD menggunakan model regresi yang sama, yang berbeda adalah variabel yang menjadi dasar perhitungan yang disesuaikan dengan kuisioner yang diberikan, model regresinya adalah :

$$
\begin{gathered}
\boldsymbol{Y} \boldsymbol{a \boldsymbol { a }}+\boldsymbol{\beta}_{\mathbf{1}} \boldsymbol{X}_{\mathbf{1}}+\boldsymbol{\beta}_{\mathbf{2}} \boldsymbol{X}_{\mathbf{2}}+\boldsymbol{\beta}_{\mathbf{3}} \boldsymbol{X}_{\mathbf{3}}+\boldsymbol{\beta}_{\mathbf{4}} \boldsymbol{X}_{\mathbf{4}}+\boldsymbol{\beta}_{\mathbf{5}} \boldsymbol{X}_{\mathbf{5}} \\
\text { dimana: } \\
\boldsymbol{a} \boldsymbol{a}=\text { Konstanta } \\
\beta_{1}=\text { koefisien regresi Tangible } \\
\beta_{2}=\text { koefisien regresi Reliability } \\
\beta_{3}=\text { koefisien regresi Responsiveness } \\
\beta_{4}=\text { koefisien regresi Assurance } \\
\beta_{5}=\text { koefisien regresi Empathy } \\
X_{1}=\text { Tangible } \\
X_{2}=\text { Reliability } \\
X_{3}=\text { Responsiveness } \\
X_{4}=\text { Assurance } \\
X_{5}=\text { Empathy } \\
Y=\text { Kepuasan Rekanan/SKPD }
\end{gathered}
$$

Indikator/variabel yang digunakan dalam menyusun pertanyaan kuisioner berdasarkan pada lima dimensi pengukuran dan dikombinasikan dengan prinsip-prinsip pelayanan publik dalam Keputusan Menteri PAN dan menyesuaikan dengan kondisi yang ada pada ULP Pemerintah Kabupaten Badung serta ketentuan yang mengatur tentang proses pelelangan.

Dalam analisis regresi linear berganda, selain mengukurkuatnya hubungan antara variabel, juga menunjukkan arah hubungan antara variabel dependen dengan variabel independen. Cara yang digunakan yaitu dengan mencari Koefisien Determinasi $\left(\mathrm{R}^{2}\right)$, melakukan Uji F serta melakukan Uji T.

Model regresi berganda (multiple regression) dapat disebut sebagai model yang baik apabila model tersebut memenuhi kriteria BLUE (Best Linear Unbiased Estimator). Keterandalan koefisien regresi yang dihasilkan dari analisis dapat diketahui dengan melakukan uji asumsi klasik meliputi uji normalitas data, uji multikolinearitasdan uji heteroskedastisitas.

\section{HASIL DAN PEMBAHASAN}

\section{SKPD}

\section{Uji Validitas dan Reliabilitas Instrumen Penelitian}

Uji validitas menggunakan 24 variabel yang diteliti menghasilkan korelasi yang terkecil sebesar 0,851 dan korelasi terbesar adalah 0,953. sedangkan $\mathrm{R}_{\text {tabel }}$ pada signifikansi 0,05 dengan jumlah data (n) sebanyak 30, maka diperoleh $\mathrm{R}_{\text {tabel }}$ sebesar 0,361. Ini berarti untuk seluruh faktor nilai $\mathrm{R}_{\text {hitung }}$ lebih besar dari $\mathrm{R}_{\text {tabel }}$. Dari uji validitas dapat diketahui bahwa pengumpulan data melalui kuisioner adalah valid sehingga dapat dilaksanakan ke analisa selanjutnya.

Uji reliabilitas Dari hasil perhitungan didapatkan koefesien Alpha Cronbach adalah sebesar antara 0,923 - 0,964 sehingga masuk ke dalam klasifikasi "Luar Biasa Bagus". Hasil pengujian reabilitas tersebut seluruhnya bermakna bahwa indikatorindikator penelitian yang dijadikan kuisioner penelitian dan dipergunakan sebagai alat pengumpul data primer ternyata dapat diandalkan untuk mengukur masing-masing dimensi.

\section{Kepuasan SKPD}

Dengan membandingkan tingkat kepuasan SKPD berdasarkan data kuisioner yang diperoleh, berikut ini ditampilkan nilai Kenyataan, harapan dan tingkat kepuasan SKPD atas layanan yang diberikan oleh ULP Pemerintah Kabupaten Badung.

Tabel 1. Kenyataan dan Harapan SKPD

\begin{tabular}{|l|c|c|c|}
\hline \multicolumn{1}{|c|}{$\begin{array}{c}\text { Indikator } \\
\text { Pertanyaan }\end{array}$} & Nilai & Nilai & Kepuasan \\
Tangible & 603 & 685 & 88,03 \\
\hline Empathy & 358 & 421 & 85,04 \\
\hline Reliability & 720 & 847 & 85,01 \\
\hline Responsiveness & 359 & 416 & 86,30 \\
\hline Assurance & 840 & 969 & 86,69 \\
\hline Total & 2880 & 3338 & 86,28 \\
\hline
\end{tabular}

Dari kelima kelompok yang telah dianalisis, keseluruhan aspek kepuasan yaitu Tangible, Empathy, Reliability, Responsiveness dan Assurance memiliki tingkat kepuasan SKPD sebesar 86,28\% berdasarkan kuisioner yang telah disebarkan kepada 30 responden.

Selanjutnya hasil perhitungan dimasukkan ke dalam diagram kartesius. 


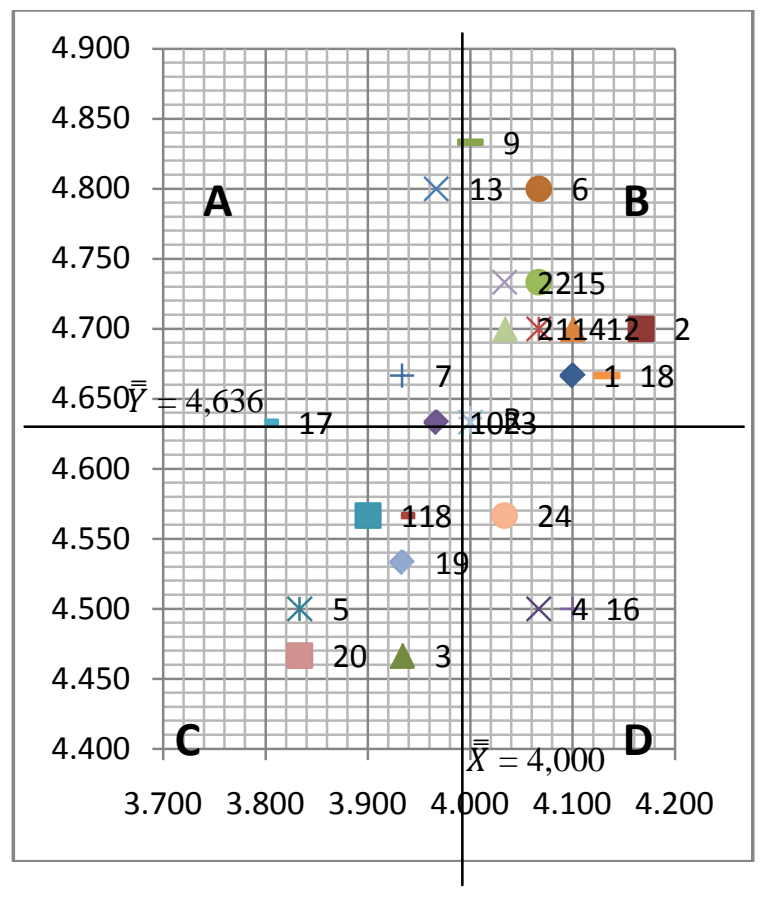

Gambar 1 Diagram Kartesius Kepuasan SKPD

1. Kuadran A ( Prioritas Utama)

Dimensi yang termasuk dalam kuadran Aadalah:

a. Dimensi 7, waktu yang disiapkan ULP untuk rapat persiapan.

b. Dimensi 9, pemahaman ULP terhadap ketentuan yang berlaku.

c. Dimensi 13, kemampuan ULP dalam memberikan penjelasan saat konsultasi.

2. Kuadran B ( Pertahankan Prestasi )

Dimensi termasuk kedalam kuadran B adalah:

a. Dimensi 1, kebersihan dan kerapian ruang kerja ULP.

b. Dimensi 2, kelengkapan peralatan kerja ULP.

c. Dimensi 6, waktu yang disiapkan ULP untuk konsultansi.

d. Dimensi 12, kemampuan ULP dalam memberikan penjelasan saat rapat penjelasan.

e. Dimensi 14, kemampuan calon pemenang yang ditetapkan oleh ULP untuk melaksanakan pekerjaan sesuai persyaratan dokumen.

f. Dimensi 15, kecepatan ULP dalam memeriksa kelengkapan dan isi dokumen lelang.

g. Dimensi 18, persyaratan ULP dalam mengajukan dokumen lelang.

h. Dimensi 21, kepatuhan ULP dalam mengikuti SOP.

i. Dimensi 22, kecepatan ULP memberikan hasil pelelangan.

3. Kuadran C ( Prioritas Rendah )

Dimensi yang termasuk dalam kuadran $\mathrm{C}$ adalah:

a. Dimensi 3, penampilan tenaga ULP. b. Dimensi 5, kondisi ruang tunggu.

c. Dimensi 8, waktu yang disiapkan ULP untuk rapat penjelasan.

d. Dimensi 10, pemahaman ULP terhadap paket yang dilelangkan.

e. Dimensi 11, ketelitian ULP dalam memeriksa dokumen lelang.

f. Dimensi 17, kecepatan dan ketelitian ULP melakukan evaluasi.

g. Dimensi 19, perlakuan ULP terhadap semua paket lelang.

h. Dimensi 20, SOP yang dimiliki ULP.

i. Dimensi 23, kelengkapan dan kejelasan dokumen akhir lelang.

4. Kuadran D ( Berlebihan )

Dimensi yang termasuk dalam kuadran D adalah:

a. Dimensi 4, papan petunjuk di ULP.

b. Dimensi 16, kecepatan ULP menghubungi SKPD untuk perbaikan dokumen lelang.

c. Dimensi 24, kejelasan ULP dalam memberikan waktu pelaksanaan proses lelang.

\section{Hubungan Antar Dimensi}

Berdasarkan model persamaan regresi di atas, data yang sudah diperoleh kemudian dimasukkan dan dianalisa sehingga diperoleh model persamaan regresi sebagai berikut :

$\mathrm{Y}=-1,812+0,044 \mathrm{X}_{1}+0,048 \mathrm{X}_{2}+0,059 \mathrm{X}_{3}+$ $0,085 \mathrm{X}_{4}+0,087 \mathrm{X}_{5}$

Berdasarkan hasil tersebut, masing-masing variable berpengaruh secara positif terhadap kepuasan SKPD dimana secara umum kenaikan sebesar 1 satuan pada setiap variabel akan meningkatkan kepuasan sebesar konstanta yang dihasilkan dengan asumsi variabel yang lain tetap. Variabel yang paling berpengaruh adalah Assurance.

Uji statistik terhadap hasil pengolahan data :

1. Uji F.

Nilai F hitung diperoleh sebesar 22,438 dan $\mathrm{F}_{\text {tabel }}$ untuk $\mathrm{N}(1)=5$ dan $\mathrm{N}(2)=30$ diperoleh nilai sebesar 2,53. Berdasarkan hasil perhitungan di atas berarti nilai $F_{\text {hitung }}$ lebih besar dari nilai $F_{\text {table }}$ $(22,438>2,53)$, dengan nilai probabilitas untuk $F$ statistik (signifikansi) adalah $0,000000<\alpha=$ 0,05 . Sehingga keputusan yang diambil adalah $H_{0}$ ditolak dan $H_{1}$ diterima yangberarti seluruh variabel bebas secara simultan/serentak signifikan mempengaruhi variabel terikat yaitu kepuasan pelanggan pada tingkat signifikansi $\alpha=$ $5 \%$.

2. Uji T

Nilai $t_{\text {tabel }}$ dengan taraf signifikan sebesar 0,05, pengujian dua sisi dengan derajat kebebasan (df) 
$=(\mathrm{n}-\mathrm{k})=(30-5)=25$ maka didapat $\mathrm{t}_{\text {tabel }}=$ 2,060. Berdasarkan hasil uji t diatas diperoleh $\mathrm{t}_{\text {hitung }}$ dari tangible $(2,067)$, reliability $(3,483)$, responsiveness $(2,732)$ dan assurance $(5,664)$ lebih besar dari $t_{\text {tabel}}$, dengan demikian maka tangible, reliability, responsiveness dan assurance berpengaruh signifikan secara parsial terhadap variabel terikat yaitu kepuasan SKPD sedangkan variable Empathy $(1,486)$ tidak berpengaruh signifikan.

3. Koefisien determinasi $\left(\mathrm{R}^{2}\right)$

Dari pengujian yang dilakukan, nilai $R^{2}$ adjustedsebesar 0,787 sehingga dapat dikatakan bahwa sebesar 78,7\% variasi variabel terikat (dalam hal ini kepuasan SKPD) dapat dijelaskan oleh variabel bebas Tangible, Empathy, Reliability, Responsiveness dan Assurance. Sedangkan sebesar 21,3\% dijelaskan oleh variabel diluar model.

Uji asumsi klasik

1. Uji normalitas

Dalam penelitian ini analisis statistik yang digunakan adalah One Sample Kolmogorov Smirnov Tes, hasilnya nilai P-value yaitu Asymp.Sig (2-tailed) bernilai 0,994 > 0,05. Disimpulkan telah memenuhi asumsi distribusi normal.

2. Uji Multikolinearitas

Dari hasil pengolahan data, diperoleh nilai VIF untuk kelima variabel bebas (tangible $=1,227$, empathy=1,117, reliability=1,112, responsiveness $=1,041$ dan assurance $=1,290$ ) lebih kecil dari 10 dan dapat disimpulkan tidak terjadi multikolinieritas.

3. Uji Heteroskedastisitas

Dari hasil analisis didapat nilai $t_{\text {hitung }}$ masingmasing variabel, sedangkan $t_{\text {tabel }}$ dapat dicari pada tabel $\mathrm{t}$ dengan $\mathrm{df}=\mathrm{n}-2$ atau $30-2=28$ pada pengujian 2 sisi (signifikansi 0,05) dan didapat hasil $=2,048$. Karena nilai $t_{\text {hitung }}$ berada pada $-2,048<t_{\text {hitung }}<2,048$, maka Ho diterima artinya tidak ada gejala heterokedastisitas.

\section{Rekanan}

Uji validitas menggunakan 31 variabel yang diteliti menghasilkan korelasi yang terkecil sebesar 0,917 dan korelasi terbesar adalah 0,982. sedangkan $\mathrm{R}_{\text {tabel }}$ pada signifikansi 0,05 dengan jumlah data (n) sebanyak 71, maka diperoleh $\mathrm{R}_{\text {tabel }}$ sebesar 0,234 . Ini berarti seluruh faktor mempunyai nilai $R_{\text {hitung }}$ lebih besar dari $\mathrm{R}_{\text {tabel }}$. Dari uji validitas dapat diketahui bahwa pengumpulan data melalui kuisioner adalah valid sehingga dapat dilaksanakan ke analisa selanjutnya.

Uji reliabilitas Dari hasil perhitungan didapatkan koefesien Alpha Cronbach adalah sebesar antara 0,971 - 0,992 sehingga masuk ke dalam klasifikasi
"Luar Biasa Bagus". Hasil pengujian reabilitas tersebut seluruhnya bermakna bahwa indikatorindikator penelitian yang dijadikan kuisioner penelitian dan dipergunakan sebagai alat pengumpul data primer ternyata dapat diandalkan untuk mengukur masing-masing dimensi.

\section{Kepuasan Rekanan}

Dengan membandingkan tingkat kepuasan Rekanan berdasarkan data kuisioner yang diperoleh, berikut ini ditampilkan nilai Kenyataan, harapan dan tingkat kepuasan Rekanan atas layanan yang diberikan oleh ULP Pemerintah Kabupaten Badung.

Tabel 2. Kenyataan dan Harapan Rekanan Masing Masing Variabel

\begin{tabular}{|l|c|c|c|}
\hline \multicolumn{1}{|c|}{$\begin{array}{c}\text { Indikator } \\
\text { Pertanyaan }\end{array}$} & $\begin{array}{c}\text { Nilai } \\
\text { Kenyataan }\end{array}$ & $\begin{array}{c}\text { Nilai } \\
\text { Harapan }\end{array}$ & $\begin{array}{c}\text { Kepuasan } \\
\text { Rekan(\%) }\end{array}$ \\
\hline Tangible & 1307 & 1531 & 85,37 \\
\hline Empathy & 1332 & 1549 & 85,99 \\
\hline Reliability & 1612 & 1863 & 86,53 \\
\hline Responsiveness & 1056 & 1230 & 85,85 \\
\hline Assurance & 2945 & 3378 & 87,18 \\
\hline Total & 8252 & 9551 & 86,4 \\
\hline
\end{tabular}

Dari kelima kelompok yang telah dianalisis, keseluruhan aspek kepuasan yaitu Tangible, Empathy, Reliability, Responsiveness dan Assurance memiliki tingkat kepuasan Rekanan sebesar 86,4\% berdasarkan kuisioner yang telah disebarkan kepada 71 responden.

Selanjutnya hasil perhitungan dimasukkan ke dalam diagram kartesius. 


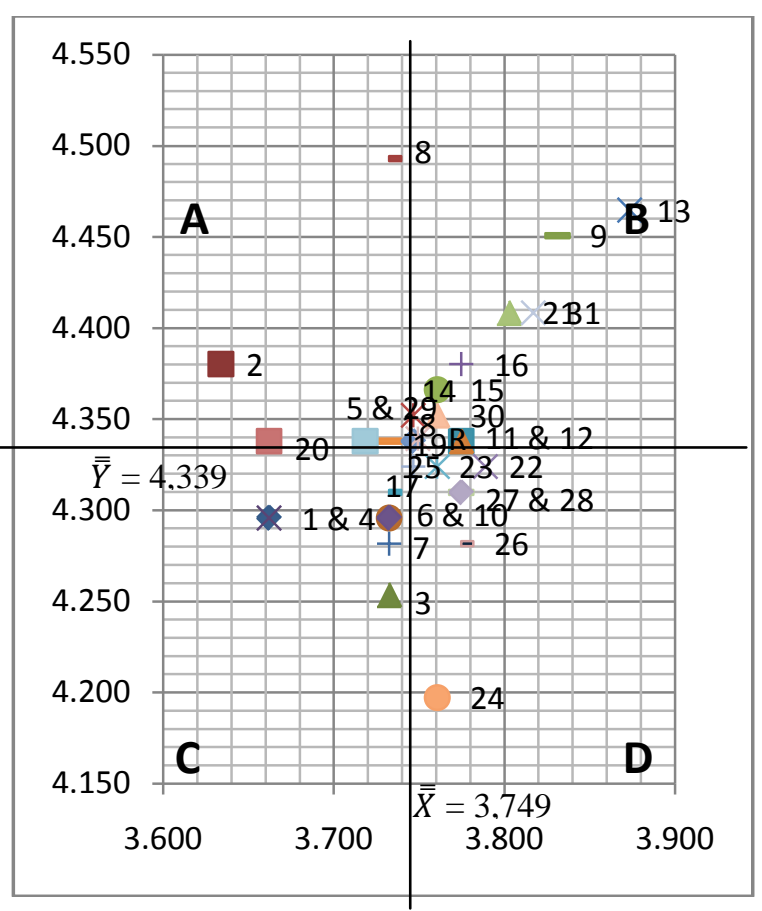

Gambar 2 Diagram Kartesius Kepuasan Rekanan

\section{Kuadran A ( Prioritas Utama)}

Dimensi yang termasuk dalam kuadran A adalah:

a. Dimensi 2, kelengkapan peralatan kerja ULP.

b. Dimensi 8, ULP bebas dari intervensi pihak lain.

c. Dimensi 14, kemampuan ULP memberikan penjelasan saat rapat penjelasan.

2. Kuadran B ( Pertahankan Prestasi )

Dimensi yang termasuk dalam kuadran B adalah:

a. Dimensi 9, kerahasiaan proses lelang oleh ULP.

b. Dimensi 13, ketelitian ULP dalam memeriksa dokumen penawaran.

c. Dimensi 15, kemampuan ULP memberikan penjelasan saat konsultasi.

d. Dimensi 16, kemampuan calon pemenang yang ditetapkan oleh ULP dalam memenuhi persyaratan dokumen lelang.

e. Dimensi 21, pengumuman lelang.

f. Dimensi 30, kepatuhan ULP pada dokumen lelang dan aturan.

g. Dimensi 31, transparansi ULP dalam proses lelang.

3. Kuadran C ( Prioritas Rendah )

Dimensi yang termasuk dalam kuadran $\mathrm{C}$ adalah:

a. Dimensi 1, kebersihan dan kerapian ruang kerja ULP.

b. Dimensi 3, penampilan tenaga ULP.

c. Dimensi 4, papan petunjuk di ULP.

d. Dimensi 5, kondisi ruang tunggu. e. Dimensi 6, waktu yang disiapkan ULP untuk konsultansi.

f. Dimensi 7, waktu yang disiapkan ULP untuk rapat penjelasan.

g. Dimensi 10, waktu yang disiapkan ULP untuk melakukan sanggahan/sanggahan banding.

h. Dimensi 17, kecepatan ULP dalam memeriksa dokumen penawaran.

i. Dimensi 18, ketelitian ULP dalam memeriksa dokumen penawaran.

j. Dimensi 19, kecepatan dan ketelitian ULP melakukan evaluasi.

k. Dimensi 20, kecepatan ULP memberikan jawaban terhadap.

l. Dimensi 25, kepatuhan ULP dalam mengikuti SOP.

m. Dimensi 29, kepatuhan ULP dalam mengikuti waktu pelaksanaan proses lelang yang telah disusun.

4. Kuadran D ( Berlebihan )

Dimensi yang termasuk dalam kuadran D adalah:

a. Dimensi 11, pemahaman ULP terhadap ketentuan yang berlaku.

b. Dimensi 12, pemahaman ULP terhadap paket yang dilelangkan.

c. Dimensi 22, persyaratan oleh ULP dalam mengajukan dokumen penawaran.

d. Dimensi 23, perlakuan dari ULP terhadap semua penawaran.

e. Dimensi 24, SOP yang dimiliki ULP.

f. Dimensi 26, kecepatan ULP memberikan hasil pelelangan.

g. Dimensi 27, kelengkapan dan Kejelasan Dokumen akhir lelang.

h. Dimensi 28, kejelasan ULP dalam memberikan waktu pelaksanaan proses lelang.

\section{Hubungan Antar Dimensi}

Berdasarkan model persamaan regresi di atas, data yang sudah diperoleh kemudian dimasukkan dan dianalisasehingga diperoleh model persamaan regresi sebagai berikut :

$\mathrm{Y}=0,258+0,097 \mathrm{X}_{1}+0,014 \mathrm{X}_{2}+0,037 \mathrm{X}_{3}+$ $0,027 \mathrm{X}_{4}+0,020 \mathrm{X}_{5}$

Berdasarkan hasil tersebut, masing-masing variabel berpengaruh secara positif terhadap kepuasan Rekanan dimana secara umum kenaikan sebesar 1 satuan pada setiap variabel akan meningkatkan kepuasan sebesar konstanta yang dihasilkan dengan asumsi variabel yang lain tetap. Variabel yang paling berpengaruh adalah Tangible. 
Uji statistik terhadap hasil pengolahan data :

1. Uji F.

Nilai F hitung diperoleh sebesar 69,118 dan $F_{\text {tabel }}$ untuk $\mathrm{N}(1)=5$ dan $\mathrm{N}(2)=71$ diperoleh nilai sebesar 2,34. Berdasarkan hasil perhitungan di atas berarti nilai $F_{\text {hitung }}$ lebih besar dari nilai $F_{\text {table }}$ $(69,118>2,34)$, dengan nilai probabilitas untuk $F$ statistik (signifikansi) adalah $0,000000<\alpha=$ 0,05 . Sehingga keputusan yang diambil adalah $H_{0}$ ditolak dan $H_{1}$ diterimayangberarti seluruh variabel bebas secara simultan/serentak signifikan mempengaruhi variabel terikat yaitu kepuasan pelanggan pada tingkat signifikansi $\alpha=$ $5 \%$.

2. Uji T

Nilai $t_{\text {tabel }}$ dengan taraf signifikan sebesar 0,05 , pengujian dua sisi dengan derajat kebebasan (df) $=(\mathrm{n}-\mathrm{k})=(71-5)=66$ maka didapat $\mathrm{t}_{\text {tabel }}=$ 1,997. Berdasarkan hasil uji t diatas diperoleh $\mathrm{t}_{\text {hitung }}$ dari tangible $(6,085)$, reliability $(2,888)$ dan assurance $(2,485)$ lebih besar dari $t_{\text {tabel}}$, dengan demikian maka tangible, reliability dan assurance berpengaruh signifikan secara parsial terhadap variabel terikat yaitu kepuasan Rekanan sedangkan variable Empathy (0,909) dan responsiveness (1,352)tidak berpengaruh signifikan.

3. Koefisien determinasi $\left(\mathrm{R}^{2}\right)$

Dari pengujian yang dilakukan, nilai $R^{2}$ adjustedsebesar 0,830 sehingga dapat dikatakan bahwa sebesar 83\% variasi variabel terikat (dalam hal ini kepuasan Rekanan) dapat dijelaskan oleh variabel bebas Tangible, Empathy, Reliability, Responsiveness dan Assurance. Sedangkan sebesar 17\% dijelaskan oleh variabel diluar model.

Uji asumsi klasik

1. Uji normalitas

Dalam penelitian ini analisis statistik yang digunakan adalah One Sample Kolmogorov Smirnov Tes, hasilnya nilai P-value yaitu Asymp.Sig (2-tailed) bernilai 0,097> 0,05. Disimpulkan telah memenuhi asumsi distribusi normal.

2. Uji Multikolinearitas

Dari hasil pengolahan data, diperoleh nilai VIF untuk kelima variabel bebas (tangible $=2,329$, empathy=2,287, reliability $=2,261$, responsiveness $=2,426$ dan assurance $=2,958$ ) lebih kecil dari 10 dan dapat disimpulkan tidak terjadi multikolinieritas.

3. Uji Heteroskedastisitas

Dari hasil analisis didapat nilai $t_{\text {hitung masing- }}$ masing variabel, sedangkan $t_{\text {tabel }}$ dapat dicari pada tabel $\mathrm{t}$ dengan $\mathrm{df}=\mathrm{n}-2$ atau 71-2 = 69 pada pengujian 2 sisi (signifikansi 0,05) dan didapat hasil $=1,995$. Karena nilai $t_{\text {hitung }}$ berada pada $-1,995<t_{\text {hitung }}<1,995$, maka Ho diterima artinya tidak ada gejala heterokedastisitas.

\section{SIMPULAN DAN SARAN}

\section{Simpulan}

Dari hasil analisis yang telah dilakukan dapat disimpulkan hal-hal sebagai berikut :

1. Tingkat kepuasan SKPD terhadap pelayanan ULP Pemerintah Kabupaten Badung adalah sebesar $86,28 \%$.

2. Dimensi yang mempengaruhi kepuasan SKPD dan penanganannya perlu diprioritaskan karena pelaksanaannya belum memuaskan (Kuadran A) adalah :

a. Waktu yang disiapkan ULP untuk rapat persiapan.

b. Pemahaman ULP terhadap ketentuan yang berlaku.

c. Kemampuan ULP dalam memberikan penjelasan saat konsultasi

3. Dimensi yang paling mempengaruhi kepuasan SKPD adalahAssurancedengan koefisien 0,087 seperti ditunjukkan pada persamaan regresi $\mathrm{Y}=$ $-1,812+0,044 X_{1}+0,048 X_{2}+0,059 X_{3}+$ $0,085 \mathrm{X}_{4}+0,087 \mathrm{X}_{5}$

4. Tingkat kepuasan Rekanan terhadap pelayanan ULP Pemerintah Kabupaten Badung adalah sebesar $86,4 \%$.

5. Dimensi yang mempengaruhi kepuasan Rekanan dan penanganannya perlu diprioritaskan karena pelaksanaannya belum memuaskan (Kuadran A) adalah :

a. Kelengkapan peralatan kerja ULP.

b. ULP bebas dari intervensi pihak lain.

c. Kemampuan ULP memberikan penjelasan saat rapat penjelasan

6. Dimensi yang paling mempengaruhi kepuasan rekanan adalah Tangible dengan koefisien 0,097 seperti ditunjukkan pada persamaan regresi $\mathrm{Y}=$ $0,258+0,097 \mathrm{X}_{1}+0,014 \mathrm{X}_{2}+0,037 \mathrm{X}_{3}+0,027 \mathrm{X}_{4}$ $+0,020 \mathrm{X}_{5}$

\section{Saran}

Berdasarkan analisis hasil dan pembahasan maka untuk meningkatkan tingkat kepuasan dari SKPD dan Rekanan, ULP Pemerintah Kabupaten Badung perlu melakukan hal-hal sebagai berikut :

1. ULP Pemerintah Kabupaten Badung harus meningkatkan kelengkapan kerja yang dimiliki.

2. ULP Pemerintah Kabupaten Badung harus menyiapkan waktu yang lebih banyak untuk melakukan rapat persiapan dengan PPK.

3. ULP Pemerintah Kabupaten Badung harus meningkatkan kemampuan dan pemahaman personilnya menyangkut ketentuan dibidang pengadaan barang/jasa sehingga dapat 
memberikan penjelasan yang baik saat konsultasi maupun saat rapat penjelasan.

4. ULP Pemerintah Kabupaten Badung harus menyiapkan prosedur operasional yang lebih baik sehingga proses pengadaan barang/jasa berjalan lebih jelas, transparan dan akuntabel sehingga dapat meminimalkan terjadinya intervensi dari pihak yang berkepentingan.

\section{DAFTAR PUSTAKA}

Bergman, Bo and Klefsjö, B., (1994), Quality from customer Needs to Customer Satisfaction, McGraw-Hill Book, England.

Irawan, H.D., (2007),10 Prinsip Kepuasan Pelanggan. Penerbit Elex Media Komputindo Kelompok Gramedia, Jakarta.

Keputusan Menteri Pendayagunaan Aparatur Negara No.63/KEP/M.PAN/7/2003 Tahun 2003 tentang Pedoman Umum Penyelenggaraan Pelayanan Publik.

Kotler, P. (2000),Manajemen Pemasaran, Edisi Milenium 1 dan 2. Prenhallindo, Jakarta.

Lovelock, Christopher H (1996),Service Marketing , 3rd edition,Prentice Hall International Editions.

Lukman, S., (1999),Manajemen Kualitas Pelayanan. Penerbit STIA LAN Press, Jakarta.

Mangkuprawira, S., dan Hubeis,A.V.,(2007),Manajemen Mutu Sumber Daya Manusia. Penerbit Ghalia Indonesia, Bogor.

Moenir, A.S., (2006),Manajemen Pelayanan Umum Di Indonesia. Penerbit Bumi Aksara, Jakarta.

Parasuraman, A-Berry,L., and Zeithaml, (1990), Delivering quality service balancing customer perception and expectation, The Free Press, New York.

Pasolong, H., (2007),Teori Administrasi Publik. Penerbit Alfabeta, Bandung.

Pawitra, T., (1993),Marketing : Dimensi, Falsafah, Disiplin dan Keahlian. Prasetya Mulya, Jakarta.

Peraturan Bupati Badung Nomor 70 Tahun 2011 tentang Pembentukan Unit Layanan Pengadaan (ULP) Pemerintah Kabupaten Badung.

Peraturan Presiden Nomor 54 Tahun 2010 Tentang Pengadaan Barang/Jasa Pemerintah.

Siregar, P., (2004),Analisis Hubungan Kepuasan Pelanggan, Nilai Pelayanan dan Kepuasan Kerja Pegawai di PT. Garuda Indonesia (tesis).Jakarta : Universitas Indonesia.

Supranto, J. (2011),Pengukuran Tingkat Kepuasan Pelanggan Untuk Menaikkan Pangsa Pasar.Cetakan ke-4.Jakarta : PT. Rineka Cipta. 